At-Turats

Jurnal Pemikiran Pendidikan Islam

journal homepage: http://jurnaliainpontianak.or.id/index.php/atturats

\title{
INOVASI KELEMBAGAAN PONDOK PESANTREN MELALUI TRANSFORMASI NILAI: STUDI KASUS DI PONDOK PESANTREN AMANATUL UMMAH PACET MOJOKERTO
}

\author{
Chusnul Chotimah, IAIN Tulungagung \\ chusnultata@gmail.com \\ Indah Khomsiyah, IAIN Tulungagung \\ indahkhomsyah@yahoo.com
}

\begin{abstract}
Islamic boarding schools are the oldest Islamic educational institutions that survive until now. The institution can survive because it continues to innovate in accordance with the demands of the times. This phenomenon also occurs in Amanatul Ummah Islamic Boarding School, which is adaptive and adoptive for the new madrasah or school system by integrating general science and religious sciences as well as preserve salafiyah values. Institutional innovation certainly does not just happen but there is a process that is taken and also the transformation of values as the power of innovation itself.

The value built by Amanatul Ummah Islamic boarding school as a basic force of institutional innovation is intangible in the form of transforming the mindset of local santri-ulama towards great santri-ulama, from santri to religious professional scientist santri, from santri local businessmen to conglomerate, from traditional santri to millennial, and from closed minded to be open-minded. Whereas the process of institutional innovation was carried out as a real implementation of the intangible values ranging from unfreezing, changing and refreezing conditions, namely only Madrasah Tsanawiyah developed to Madrasah Aliyah, Excellence of Madrasah Aliyah, Accelerated of Madrasah Programs, and International of Standard Madrasah (MBI).
\end{abstract}

Key Word: Inovasi, Pondok Pesantren, Transformasi Nilai

\section{PENDAHULUAN}

Lembaga pendidikan Islam pertama di Indonesia adalah pesantren. Fakta menegaskan bahwa pesantren telah berkontribusi nyata dalam mencetak generasi intelektual yang siap mengaktualisasikan ilmunya di masyarakat. $^{1}$ Terdapat sekitar 7.000an pesantren dengan jumlah santri kurang lebih sekitar 11 juta orang dan ustadz/ah sekitar 150 ribu. $^{2}$ Jumlah tersebut sangat strategis dan menguntungkan bagi pembangunan bangsa Indonesia, terutama

\footnotetext{
1 Imam Tolkhah dan Barizi, Membuka Jendela Pendidikan-Mengurai Akar Tradisi, (Jakarta: PT. Raja Grafindo Persada, 2004), 49

2 Farid Ma'ruf Hariadi, “Arah Baru Pengelolaan Pondok Pesantren", dalam Episteme Jurnal Pengembangan Ilmu Keislaman, vol. 3, Juni 2008, 92
} 
At-Turats

Jurnal Pemikiran Pendidikan Islam

journal homepage: http://jurnaliainpontianak.or.id/index.php/atturats

dalam pemberdayaan sumberdaya manusia yang berkarakter.

Nurcholish Madjid telah memprediksikan pesantren sebagai sesuatu yang dapat dijadikan alternatif terhadap sistem yang ada. ${ }^{3}$ Dalam mewarnai sejarah panjang perjalanan bangsa ini, sebagai lembaga pendidikan tertua, pesantren berkontrbusi tidak hanya dalam aspek pendidikan saja melainkan juga bidang lain dalam skala yang luas. ${ }^{4}$

Hal yang unik dari pondok pesantren adalah memiliki kedaulatan leadership sepenuhnya di bawah kharisma kiai yang sifatnya independent dalam segala hal, ${ }^{5}$ dan hingga saat ini masih bertahan. Dalam perkembangan sekarang, lembaga pendidikan Islam tertua ini, ${ }^{6}$ dalam perkembangan era sekarang memiliki tanggung jawab lebih berat dalam hal mengangkat arus perubahan sosial sebagai dampak dari era gobalisasi. Problema dekadensi moral, kemiskinan, melesatnya ilmu pengetahuan dan teknologi memerlukan langkah konkrit pesantren sebagai untuk merespon situasi dan kondisi tersebut dengan membuka

\footnotetext{
${ }^{3}$ Yasmadi, Modernisasi Pesantren, Kritik Nurcholis Madjid terhadap pendidikan islam tradisional, (Jakarta: Quantim Teaching , 2005 ), 59.

${ }^{4}$ Moh. Ahyadi, "Pesantren, Kiai, dan Tarekat: Studi tentang Peran Kiai di Pesantren dan Tarekat", dalam Abuddin Nata, Sejarah Pertumbuhan dan Perkembangan Lembaga-Lembaga Pendidikan Islam di Indonesia, (Jakarta: Grasindo, 2001), 133

${ }^{5}$ Achmad Patoni, Peran Kiai Pesantren Dalam Partai Politik, (Yogyakarta : Pustaka Pelajar, 2007 ), 90-91.

${ }^{6}$ Muhaimin mengelompokkan pendidikan Islam ditinjau dari aspek program dan praktik penyelenggaraannya menjadi lima jenis, yaitu (1) pendidikan pondok pesantren dan madrasah diniyah; (2) pendidikan madrasah sebagai sekolah umum berciri khas agama; (3) pendidikan umum yang bernafaskan Islam seperti SD Islam, SMP Islam dsb.; (4) pelajaran agama Islam yang diselenggarakan di sekolah sebagai mata pelajaran; dan (5) pendidikan Islam dalam keluarga atau majlis-majlis ta'lim. Lihat Muhaimin, Pengembangan Kurikulum Pendidikan Agama Islam di Sekolah, Madrasah dan Perguruan Tinggi, (Jakarta: Raja Grafindo Persada, 2005), 9-10
}

diri dalam merespon perubahan dengan melakukan inovasi kelembagaan. Inovasi yang dilakukan tentunya tanpa mengurangi nilai-nilai keikhlasan, kharismatik, dan kewibawaaan. Di sinilah pondok pesantren harus bersikap adaptif dan adoptif terhadap sistem baru seperti madrasah atau sekolah, menyempurnakan kurikulum yang digunakan sesuai tuntutan zaman, serta menyesuaikan pola kepemimpinan pesantren dari patternalistik menuju demokratis.

Strategi inilah yang harus ditempuh pondok pesantren jika mau bertahan. Selain itu ada hal-hal lain yang harus dipertahankan oleh pondok pesantren, seperti: dalam hal penanaman nilai, pesantren mempertahankan akulturasi budaya jawa sebagaimana pernyataan Zahra yang menyatakan bahwa pesantren mempertahan kultur Jawa yang mampu menyerap kebudayaan luar melalui suatu proses internalisasi tanpa kehilangan identitasnya merupakan cara pesantren mempertahankan eksistensi diri. $^{7}$ Demikian pula dengan jiwa kewirausahaan juga merupakan strategi pesantren dalam mempertahankan diri sebagaimana pendapat Aya Sofia yang menyatakan bahwa selama ini ketahanan pondok pesantren itu disebabkan oleh jiwa dan semangat entrepreneur yang tinggi. ${ }^{8}$ Sementara disisi lain Langgulung berpendapat bahwa kedayatahanan pesantren itu pada hakekatnya sebagai akibat dari pribadi leader dalam hal ini

7 Azyumardi Azra, "Surau di Tengah Krisis: Pesantren dan Perspektif Masyarakat", dalam Rahardjo ed., Pergulatan Dunia Pesantren Membangun dari Bawah, (Jakarta: LP3ES, 1985), 173

8 Aya Sofia, et.al., Pedoman Penyelenggaraan Pusat Informasi Pesantren, (Jakarta: Proyek Pembinaan dan Bantuan Kepada Pondok Pesantren di Jakarta 1985/1986), 41 
At-Turats

Jurnal Pemikiran Pendidikan Islam

journal homepage: http://jurnaliainpontianak.or.id/index.php/atturats

kiai yang kompeten dengan ilmu dan visinya. $^{9}$

Ketahanan yang disebabkan oleh dominannya faktor internal ini, mampu memberikan konstribusi terhadap ketahanan pesantren. Ditambah polarisasi perubahan pesantren yang menyesuaikan diri dengan tuntutan zaman, dengan melakukan berbagai inovasi dalam manajemen, yaitu inovasi lembaga dengan didirikannya madrasah atau sekolah umum di pesantren. Berdirinya madrasah atau sekolah umum di pesantren merupakan implementasi integrasi keilmuan yang melahirkan generasi handal berbekal ilmu pengetahuan, iman dan takwa serta mampu menjadi pemimpin yang amanah. Hal ini sebagaimana pernyataan Mukti Ali yang menyatakan bahwa: "Tidak sedikit pemimpin-pemimpin negeri ini, baik pemimpin yang duduk dalam pemerintahan atau bukan, besar ataupun kecil, yang dilahirkan oleh pondok pesantren". 9 Manakala pesantren tidak segera berbenah dan melakukan inovasi baik dalam keilmuan maupun manajemen maka tidak diragukan lagi pesantren akan tergerus oleh arus zaman.

Fenomena tersebut di atas terjadi pada pesantren Amanatul Ummah Pacet Mojokerto, di mana secara historis pesantren ini berawal dari pesantren salaf yang melakukan inovasi kelembagaan dengan mengintegrasikan ilmu umum dan agama melalui pendirian madrasah unggulan berbasis keilmuan dan sekolah umum berbasis pesantren. Untuk mempertahankan eksistensi pesantren, Amanatul Ummah membuat program-program unggulan yang keluar dari pakem standar out of the box pesantren salafi yang dianggap rigid. Inovasi kelembagaan tersebut secara garis besar seperti: pondok pesantren program unggulan, pondok pesantren program MBI, pondok pesantren program akselerasi, dan pondok pesantren program full beasiswa. Dalam semua program tersebut pesantren Amanatul Ummah tentunya bukan tidak terjadi begitu

9 Hasan Langgulung, Pendidikan Islam Menghadapi Abad ke-21, (Jakarta: Pustaka Al- Husna, 1988), 75 saja melainkan ada proses planning yang matang terutama dalam merubah mindset para pengasuh maun santri di lingkungan pondok pesantren tentang visi, misi, dan goal dari pondok pesantren itu sendiri. Perubahan mindset tersebut ke arah peningkatan kualitas keilmuan dan keterampilan yang baik, akhlakul karimah dan pesantren memproses lulusan MA PP Unggulan Amanatul Ummah untuk bisa studi lanjut ke perguruan tinggi yang berkualitas pada fakultas-fakultas pilihan Agama, Kedokteran, Farmasi, Teknik dan Ekonomi baik yang ada di luar negeri maupun yang ada di luar negeri. Inovasi inilah yang belum ditemukan di pesantren lain, karena pesantren Amanatul Ummah benar-benar menjamin para lulusannya dan menghantarkan para santri lulusan untuk studi lanjut. Manakala santri belum mendapatkan tempat untuk studi lanjut maka santri tidak diperkenankan untuk pulang. Dan inilah bukti riil pesantren melakukan inovasi out of box.

\section{KERANGKA KONSEPTUAL}

\section{Konsep Dasar Inovasi Kelembagaan}

Istilah inovasi identik dengan change. Change itu sendiri terpilah menjadi dua: perubahan alamiah dan perubahan non alamiah (disengaja). Perubahan yang pertama bersifat natural, sedangkan perubahan kedua salah satunya melalui pendidikan. Hakekat perubahan dapat dimaknai sebagai the before condition, yaitu beralihnya keadaan sebelumnya menjadi the after condition keadaan sesudahnya. ${ }^{10}$ Dalam literatur lain, perubahan diterangkan dengan kata transitions, walaupun menurut William mengandung arti berbeda. Perbedaannya adalah transisi lebih mengarah pada perubahan secara fundamental dan mendasar, sedangkan

10 Winardi, Manajemen Perubahan, (Jakarta: Kencana, 2005), 1 


\section{At-Turats}

Jurnal Pemikiran Pendidikan Islam

journal homepage: http://jurnaliainpontianak.or.id/index.php/atturats

perubahan atau change lebih mengarah pada perubahan secara umum. ${ }^{11}$

Perubahan, hakekatnya adalah proses transformasi dari situasi sekarang menuju situasi yang diharapkan di masa yang akan dating. ${ }^{12}$ dalam konteks kajian ini, perubahan ang dimaksud adalah perubahan yang diharapkan membawa kemajuan dan kemaslahatan hidup. James L. Price mencoba membuat distingsi "Innovation is a less general term than social change, that is, any modification of the social structure and / or culture of a social system. All innovation is social change, but not all social change is innovation". ${ }^{13}$ (Pembaruan adalah istilah yang kurang lazim dalam perubahan sosial, yakni suatu modifikasi dari sebuah struktur sosial dan atau budaya dari sistem sosial. Seluruh pembaruan adalah perubahan social, tetapi tidak semua perubahan sosial adalah suatu pembaruan).

Sementara itu Nursyam berpendapat perubahan merupakan suatu inovasi. Inovasi bisa datang dari intern maupun ekstern, adanya skenario akseleratif untuk berubah/melakukan perubahan, dan adanya motivasi kuat untuk berubah. ${ }^{14}$ Inovasi mencakup perubahan dari arah negatif menuju positif, dari inefectif change menuju efectif change, dan dari partial change menuju global change. Jadi istilah inovasi selalu mengarah kepada

${ }^{11}$ William Bridges, Managing Transitions: Making the Most of Change, (Cambridge: Perseus Publishing Services, 2003), 3

${ }^{12}$ Wibowo, Manajemen Perubahan, (Jakarta: PT Raja Grafindo Persada, 2006), .1

13 James L. Price, Handbook of Organizational Measurement, (London : DC. Health and Company, 1972), 118

14 Nursyam, "Indikator dan Pengukuran Pengembangan SDM di Pesantren", dalam A. Halim et. al., Manajemen Pesantren, (Yogyakarta : Pustaka Pesantren, 2005), 62 pembaharuan, ${ }^{15}$ sedangkan pembaharuan belum tentu didalamnya ada inovasi. Dalam kajian ini inovasi dipilih karena penulis lebih fokus pada transformasi nilai yang diaktualisasikan pengasuh dalam habitus sebagai pijakan pembaharuan pondok pesantren.

\section{Teori Inovasi Kelembagaan}

Ada beberapa teori inovasi yang berhasil penulis lacak, dimana ada penggunaan term yang berbeda dari masing-masing tokoh. Ada yang menggunakan istilah inovasi dengan term movement, changing yang berarti perubahan, namun ada pula yang berpendapat bahwa changing dengan inovasi itu berbeda. Istilah changing digunakan oleh Kreitner dan Kinicki serta Greenberg dan Baron, sedangkan movement digunakan oleh Robbins ${ }^{16}$, sedangkan Schein menggunakan terminologi unfreezing, cognitive restructuring, dan refreezing. ${ }^{17}$ Ketiga hal tersebut merupakan proses cognitive restructuring dalam suatu inovasi kelembagaan.

Terminologi yang digunakan Schein senada dengan Lewin yang mengembangkan tiga tahap model perubahan, mulai dari proses inisiatif, pengelolaan, dan proses stabilisasi perubahan itu sendiri. Dalam kajian ini penulis cenderung ke teori Lewin yang memerinci proses inovasi menjadi tiga tahapan sebagai berikut:

1) Unfreezing, adalah tahapan yang menekankan pada proses membangun motivasi untuk berubah. Unfreezing

15 Inovasi mengacu kepada pembaharuan suatu produk, proses dan jasa baru. Lihat Lena Ellitan dan Lina Anatan, Manajemen Inovasi: Transformasi Menuju Organisasi Kelas Dunia, (Bandung: Alfabeta, 2009), 3.

16 Lihat Robbins, Teori Organisasi Behaviour, (New Jersey: Prentice Hall, Inc, 1991), 421.

17 Edgar H. Schein, Organizational Culture and Leadership, (San Fransisco: Jossey-Bass, 1997), 298 


\section{At-Turats}

Jurnal Pemikiran Pendidikan Islam

journal homepage: http://jurnaliainpontianak.or.id/index.php/atturats

merupakan kondisi pencairan dari status quo.

2) Cognitive Structuring (Changing), adalah proses movement atau cognitive restructuring, dimana semua pelaku lembaga atau organisasi diberi informasi baru, model perilaku baru, atau cara baru dalam melihat sesuatu. Proses changing ini membangun kesadaran pelaku organisasi dan dilakukan secara kontinyu.

3) Refreezing (pembekuan kembali), adalah proses distabilisasi melalui pembekuan guna membantu pelaku organisasi mengintegrasikan perilaku dan sikap yang telah berubah kedalam keadaan yang normal dan menjadi norma-norma baru yang diakui kebenarannya. Proses ini merupakan siklus tiada henti namun dilakukan secara terus-menerus.

Penjelasan mengenai tahapan tersebut diatas dapat dikemukakan dengan gambar sebagai berikut:

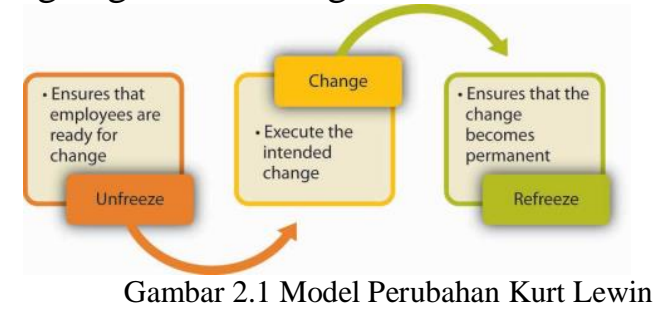

\section{Transformasi Nilai}

\section{a. Konsep Dasar Transformasi Nilai}

Transformasi merupakan perubahan format atau bentuk. Transformasi sendiri berasal dari kata transformare yang berarti mengubah bentuk. Hal ini sebagaimana diungkap oleh Wasito yang menyatakan bahwa transformasi adalah formation yang berarti bentuk. ${ }^{18} \mathrm{Hal}$ ini diteguhkan oleh Komaruddin yang menyatakan bahwa transformasi adalah perubahan bentuk atau struktur, bisa juga diartikan dengan konversi dari satu bentuk ke bentuk lainnya. ${ }^{19}$ Penjelasan

\footnotetext{
${ }^{18}$ S. Wojowasito, Tito Wasito W, Kamus Lengkap Inggris-Indonesia, Indonesia- Inggris, (Bandung: Penerbit Hasta, 1982).

${ }^{19}$ Komaruddin, Kamus Riset, (Bandung: Angkasa, 1984), 285
}

lebih lanjut sebagaimana pendapat Raharjo mendefinisikan transformasi sebagai berikut: pertama, transformasi berkaitan dengan pengertian yang menyangkut perubahan mendasar berskala besar dalam masyarakat dunia, yang beralih dari tahap masyarakat industri menjadi masyarakat informasi. Kedua, pengertian tentang terjadinya transformasi itu timbul dari kajian historis, yang menyimpulkan bahwa selama kurang lebih dua atau tiga abad terakhir telah terjadi perubahan fundamental dari masyarakat agraristradisional menuju masyarakat industrialmodern. ${ }^{20}$

Paparan tersebut menunjukkan bahwa transformasi adalah proses perubahan secara bertahap dan terusmenerus sehingga sampai pada tahap ultimate, perubahan yang dilakukan dengan cara memberi respon terhadap pengaruh unsur eksternal dan internal yang akan mengarahkan perubahan dari bentuk yang sudah dikenal sebelumnya melalui proses melipatgandakan secara berulang-ulang. Sebuah transformasi bukannya perubahan yang bersifat instan, namun dilakukan secara berangsurangsur dan dilakukan secara kontinyu. Hal ini sebagaimana pendapat Yazid yang menyatakan bahwa transformasi merupakan perubahan yang terjadi secara perlahan-lahan atau sedikit demi sedikit, yang sifatnya tidak dapat diduga kapan start dan finish, bersifat komprehensif berkelanjutan dan berkaitan dengan emosional sistem nilai yang tumbuh di masyarakat. $^{21}$

Proses berkelanjutan tersebut mengandung dimensi waktu dan dimensi

\footnotetext{
${ }^{20}$ Dawam Rahardhjo, Pesantren dan Pembaharuan, (ttp: LkiS, 1995), 98

${ }^{21}$ Moh. Yazid, Transformasi Nilai, http://mohyazid168.blogspot.co.id/2016/02/transporma si- nilai-etika-dan-moral.html
} 
At-Turats

Jurnal Pemikiran Pendidikan Islam

journal homepage: http://jurnaliainpontianak.or.id/index.php/atturats

sosial. Dimensi tersebut dilalui dalam proses yang tidak singkat dan terkait dengan aktifitas yang terjadi pada saat itu. Konsep ini sesuai dengan perspektif Islam yang memandang bahwa transformasi sosial merupakan sebuah dinamika dan terjadi secara terus menerus. Konsep tersebut terangkum dalam amar ma'ruf nahi munkar yang bersifat transendens. ${ }^{22}$ Transendensi tersebut berkaitan erat dengan nilai, dan nilai inilah yang terus melakukan proses transformasi. Nilai berkaitan erat dengan hal baik dan buruk. Sesuatu yang diyakini akan kebenarannya, dia dihargai dan akan terus diperjuangkan itulah nilai. Bahkan indicator untuk menentukan suatu tindakan diperbolehkan atau dilarang, dihukum atau diberi ganjaran itu adalah nilai. $^{23}$ Secara kualitas empiris, nilai susah untuk didefinisikan, ${ }^{24}$ namun walaupun tidak bisa didefinikan bukan berarti nilai tidak bisa dipahami. ${ }^{25}$

Nilai dipahami sebagai sebuah pikiran (idea) atau konsep mengenai apa yang dianggap penting bagi seseorang dalam kehidupannya. ${ }^{26}$ Mulyana menegaskan bahwa nilai adalah keyakinan yang membuat seseorang bertindak atas dasar pilihannya. ${ }^{27}$ Nilai adalah patokan normatif yang mempengaruhi seseorang tatkala

\footnotetext{
${ }^{22}$ Kuntowijoyo, Demokrasi dan Budaya Birokrasi, (Yogyakarta: Bentang, 1994), 338

23 Khoiron Rosyadi, Pendidikan Profetik, Cet.1 (Yogyakarta: Pustaka Pelajar, 2004), 114.

24 Abdul Latif, Pendidikan Berbasis Nilai Kemasyarakatan, (Bandung: Refika Aditama, 2006), 69.

${ }^{25}$ Louis O.Katsoff, Elements of Philosophy, terj. Soejono Soemargono, (Yogyakarta: Tiara Wacana, 1989), 335

26 Madyo Ekosusilo, Hasil Penelitian Kualitatif Sekolah Unggul Berbasis Nilai: Studi Multi Kasus di SMAN 1, SMA Regina Pacis, dan SMA al-Islam 01 Surakarta, (Sukoharjo: UNIVET Bantara Press, 2003), 22

${ }^{27}$ Rohmat Mulyana, Mengartikulasikan Pendidikan Nilai, (Bandung: Alfabeta, 2004), 9.
}

menentukan pilihan di antara tindakan alternatif, ${ }^{28}$ yang pada akhirnya seseorang akan memutuskan ya atau tidak. Hal inilah yang akhirnya membedakan perilauu individu satu dengan lain atau kelompok satu dengan kelompok lain sebagaimana pendapat Kuchloh yang dikutip Mulyana mengatakan bahwa "nilai sebagai konsepsi (tersirat atau tersurat, yang sifatnya membedakan individu atau ciri-ciri kelompok) dari apa yang diinginkan, yang mempengaruhi pilihan terhadap cara, tujuan antara dan tujuan akhir tindakan". ${ }^{29}$

Jadi nilai adalah suatu keyakinan yang menjadi dasar bagi seseorang atau sekelompok orang untuk menentukan tindakannya, menilai baik atau buruk, bermakna atau tidak bermakna bagi kelangsungan hidup. Nilai penting untuk dibangun dan ditransformasikan karena nilai meletakkan fondasi untuk memahami sikap dan motivasi serta mempengaruhi persepsi individu atau kelompok. Individu-individu memasuki suatu organisasi dengan gagasan yang dikonsepsikan sebelumnya mengenai apa yang "seharusnya" dan "tidak seharusnya". Tentu saja gagasan-gagasan itu tidak bebas nilai karena berangkat dari subyektifitas, ${ }^{30}$ yang mmenurut Robbins nilai individu itulah yang akan mempengaruhi sikap dan perilaku individu dan kelompok. ${ }^{31}$ Hanya dengan transformasi nilai maka perubahan akan terjadi. Dan inilah kunci dari suatu inovasi kelembagaan.

\section{b. Macam-Macam Nilai}

Spranger, sebagaimana dikutip Mulyana, mengemukakan "enam orientasi nilai yang sering dijadikan rujukan oleh manusia dalam

\footnotetext{
${ }^{28}$ Ibid., 9.

${ }^{29}$ Ibid.

${ }^{30}$ S.P. Robbins, Organizational ..., 158

${ }^{31}$ Ibid., 159
} 


\section{At-Turats}

Jurnal Pemikiran Pendidikan Islam

journal homepage: http://jurnaliainpontianak.or.id/index.php/atturats

kehidupannya", yaitu: nilai estetik, nilai teoritik, nilai ekonomis, nilai sosial, nilai politik, dan nilai agama. ${ }^{32}$ Sedang tinggi rendahnya nilai dikelompokkan menjadi 4 tingkatan sebagai berikut: 1) Nilai-nilai kenikmatan; 2) Nilai-nilai kehidupan; 3) Nilai-nilai kejiwaan; 4) Nilai-nilai kerohanian. ${ }^{33}$ The Liang Gie mengklasifikasi jenis nilai menjadi empat, yaitu:1) Kekudusan (holiness): kebaikan sekaligus suatu kebenaran; 2) Kebaikan (goodness): kekudusan sekaligus keindahan; 3) Kebenaran (truth): keindahan sekaligus kekudusan; 4) Keindahan (beauty): kebenaran sekaligus kebaikan. Klasifikasi tersebut bermakna bahwa suatu hal yang sungguh indah itu adalah kebenaran bagi yang bisa menikmati, sekaligus hal baik yang ingin terus dinikmati. ${ }^{34}$

Lebih lanjut Kluckhohn, sebagaimana dikutip Kuntjaraningrat ${ }^{35}$ mengemukakan bahwa nilai dalam kebudayaan masyarakat pada hakekatnya mencakup 5 masalah mendasar yaitu: 1) Nilai mengenai hakikat hidup manusia; 2) Nilai mengenai hakikat karya manusia; 3 ) Nilai mengenai hakikat kedudukan manusia yang berorientasi pada masa lalu, masa kini, dan masa depan; 4) Nilai mengenai hakikat manusia dengan sesama manusia; dan 5). Nilai mengenai hakikat hubungan manusia dengan alam.

Berbagai macam nilai sebagaimana dipaparkan dalam uraian tersebut di atas dijadikan pijakan dasar dalam pembahasan artikel ini. Proses transformasi nilai merupakan pijakan dasar dalam pengembangan kelembagaan

\footnotetext{
${ }^{32}$ Mulyana, Mengartikulasikan Pendidikan...., 3233.

${ }^{33}$ Ekosusilo, Hasil Penelitian..., 27

${ }^{34}$ The Liang Gie, Pengantar Filsafat Ilmu, (Yogyakarta: Liberty, 2010).

${ }^{35}$ Koentjaraningrat, Kebudayaan, Mentalitas, dan Pembangunan. (Jakarta: Gramedia, 1989), 56
}

dimana dengan adanya transformasi nilai inilah inovasi kelembagaan bermula.

\section{METODE PENELITIAN}

Kajian artikel ini terpaparkan sebagai hasil dari analisis pengumpulan data yang dilakukan melalui tiga metode yaitu: wawancara mendalam (indepth interview), observasi partisipan (participant observation), dan studi dokumentasi (study document) ${ }^{36}$ di lokasi penelitian. Wawancara dilakukan kepada kiai, pengasuh, ustadz/ah, stakeholder, maupun santri, sedangkan observasi dilakukan oleh peneliti langsung dengan hadir di lokasi penelitian selaku key instrument. Dalam analisis selanjutnya peneliti bertindak sebagai instrument sekaligus pengumpul data, karena dalam penelitian kualitatif instrumen utama (key person-nya) adalah manusia. ${ }^{37}$ sedangkan dokumentasi dilakukan peneliti terhadap data-data pendukung yang tertuang dalam paper, foto, naskah, ataupun berkasberkas lain yang mendukung terhadap tema kajian.

Penelitian ini merupakan penelitian kualitatif ${ }^{38}$ dengan analisis data bermadzhab Milles and Hubberman, dimana data yang terkumpul di reduksi, di verifikasi, dipaparkan, dan selanjutnya ditarik pada kesimpulan atau benang merah. $^{39}$ Dalam penggalian data di lapangan, peneliti menggunakan pendekatan fenomenologi, ${ }^{40}$ dimana

\footnotetext{
${ }^{36}$ Bogdan dan Biklen, Qualitative Research Qualitative Research for Education: An Introduction to Theory and Methods.(Allyn and Bacon, Inc.: Boston London, 1982), 119-143.

${ }^{37}$ Rochiati Wiriaatmaja, Metode Penelitian Tindakan Kelas, (Bandung: PT. Rosdakarya, 2007), 96.

${ }^{38}$ Lexy J Moleong, Metode Penelitian Kualitatif,

(Bandung: Remaja Rosda Karya, 1990), 2

${ }^{39}$ B. Mathew Miles dan Michael Huberman, Analisis Data Kualitatif Buku Sumber Tentang Metodemetode Baru, (Jakarta: UIP, 1992), 22

${ }^{40}$ Sanapiah Faisal, Penelitian Kualitatif: DasarDasar dan Aplikasi, (Malang: YA3, 1990), 22
} 
At-Turats

Jurnal Pemikiran Pendidikan Islam

journal homepage: http://jurnaliainpontianak.or.id/index.php/atturats

kasus yang diangkat dalam kajian ini memang benar-benar berdasar fenomena yang terjadi di pondok pesantren Amanatul Ummah dan bersifat naturalistik dalam arti bukan hal yang dibuat-buat atau sengaja dilakukan untuk kepentingan tertentu.

\section{PEMBAHASAN HASIL PENELITIAN}

\section{Nilai Intangible sebagai Kekuatan Dasar Inovasi Kelembagaan di Pondok Pesantren Amanatul Ummah}

Nilai adalah suatu keyakinan, hal yang diyakini kebenarannya, dipegang teguh dan yang harus diperjuangkan. ${ }^{41}$ Sedangkan intangible dalam kamus bahasa Indonesia adalah tidak kentara, hal-hal yang tidak dapat diraba. $^{42}$ Memang nilai adalah suatu keyakinan yang tidak terlihat oleh panca indrawi, namun aktualisasi dari nilai itu bisa dirasakan dalam interaksi, lingkungan sosial, maupun lembaga organisasi. Bahkan nilai yang sifatnya intangible merupakan kekuatan utama sebuah lembaga melakukan inovasi. Dan hal ini terjadi pada pondok pesantren Amanatul Ummah Pacet Mojokerto, dimana pondok pesantren ini mengalami perkembangan yang cukup pesat. Perkembangan terjadi karena adanya perubahan, sementara perubahan sendiri termanifes manakala ada inovasi. Iovasi inilah sebagai kekuatan dasar yang sifatnya intangible bisa berupa ide, gagasan, pikiran, pandangan, dan lain-lain yang kesemuanya sarat dengan nilai.

Nilai yang dibangun pondok pesantren Amantul Ummah sebagai kekuatan dasar dalam inovasi kelembagaan diawali dari tokoh pendiri itu sendiri, dimana muncul kegelisahan kiai atas fenomena pendidikan saat ini yang dikuasai orang barat. Hal ini tidak lain karena generasi Islam hanya menguasai ilmu agama saja dan tidak adaptif terhadap ilmu lain. Dari sinilah inovasi nilai

\footnotetext{
${ }^{41}$ Khoiron Rosyadi, Pendidikan Profetik, 114.

42 https://kamuslengkap.com/kamus/inggrisindonesia/arti-kata
}

intangible mulai digerakkan. Penggerakkan nilai ini berjalan secara perlahan dan berangsur-anngsur namun bersifat kontinyu. Diawali dengan usaha penggeseran mindset tentang pondok pesantren salafiyah yang hanya mengkaji ilmu agama saja, bergeser pada pesantren ahli ilmu agama dan professional ilmu umum. Pondok pesantren harus adaptif, adoptif, dan akomodatif terhadap perkembangan zaman, karena hal ini yang dibutuhkan masyarakat. Secara garis besar nilai yang dibangun sebagai kerangka dasar inovasi kelembagaan pondok pesantren adalah nilai integrasi keilmuan.

Secara terperinci penjabaran nilai intangible yang dibangun pondok pesantren Amanatul Ummah sebagai kekuatan dasar inovasi adalah mengacu pada pergeseran mindset para santri dan pengelola yang termaktub pada nilai sebagai berikut:

Pertama, pergeseran mindset santri dari ulama lokal menjadi ulama besar yang akan dapat menerangi dunia dan Indonesia, dan menjadi para pemimpin dunia dan pemimpin bangsanya yang akan mengupayakan kesejahteraan dan menegakkan keadilan utamanya di bumi Indonesia. Nilai yang ditanamkan merupakan nilai yang adaptif dan akomodatif terhadap kebutuhan perkembangan zaman, yaitu berdirinya sekolah formal di pesantren. Ide dan gagasan adaptif mendirikan sekolah ini sesuai dengan tuntutan perkembangan jaman dan dibutuhkan oleh masyarakat, dengan tetap mengaktualisasikan nilai-nilai tradisional Islam itu sendiri. Aktualisasi dari ide atau gagasan kiai selaku pendiri bukan berarti tanpa rintangan. Semuanya penuh dengan perjuangan. Nilai-nilai perjuangan yang ditanamkan pada para santri. Perjuangan yang diilhami oleh kekuatan religious. Konsep ini dalam perspektif Islam adalah amar ma'ruf nahi munkar yang bersifat transendens. ${ }^{43}$

Nilai-nilai di atas mampu digunakan untuk merubah paradigma santri dari yang tujuan mulanya mungkin hanya sebagai pegawai atau pekerja menjadi bertujuan

\footnotetext{
${ }^{43}$ Kuntowijoyo, Demokrasi dan Budaya Birokrasi, (Yogyakarta: Bentang, 1994), 338
} 
At-Turats

Jurnal Pemikiran Pendidikan Islam

journal homepage: http://jurnaliainpontianak.or.id/index.php/atturats

transformatif. Dalam merubah mindset santri, maka perlu penanaman cukup lama, bukan hanya mengingatkan namun membiasakan santri untuk melakukan sesuatu yang sifatnya terus-menerus. Tidak hanya mindset santri yang berubah, namun masyarakat luas juga mulai menerima bahkan mengharap mindset tersebut segera terealisasi dalam kehidupan nyata. Hal ini selaras dengan pendapat Efendi dalam Fauzi yang mengatakan, ${ }^{44}$ kehadiran kiai dan pesantren di tengah-tengah masyarakat dipandang sebagai fenomena sosial yang unik untuk dikaji, sejak awal abad ke-XX peran sosial kiai telah memainkan perannya secara signifikan dan melahirkan sistem nilai dalam kehidupan pesantren. Karena itu, internalisasi nilai-nilai dimaksud, pada hakikatnya tidak lepas dari peran kiai dibidang sosial, kegamaan, maupun pendidikan. Demikian sistem nilai tersebut, menjadi keyakinan dan nilai dasar (core belief, core values), sekaligus sebagai modal sosial kiai dalam membangun model kepemimpinan transformatif.

Kedua, dari santri agamis menjadi santri profesional religius dan bertanggung jawab. Ketiga, dari santri pebisnis lokal menjadi konglomerat besar yang dapat memberi kontribusi maksimal terhadap terwujudnya kesejahteraan bangsa Indonesia. Transformasi nilai tersebut digagas oleh Asep selaku kiai pondok pesantren Amanatul Ummah yang menjadi power bagi seluruh pengasuh dan santri. Santri professional disini adalah santri yang tidak hanya professional di bidangn agama saja melainkan juga professional di bidang umum. Demikian pula untuk menjadi konglomerat besar harus bermodal wawasan luas tidak skeptic namun tetap memegang teguh ajaran Islam. Nilai yang ditanamkan kiai Asep ini meunjukkan bahwa kiai Asep mencoba untuk mengidentifikasi segala fenomena yang ada dalam organisasi pendidikan dengan tubuh, pikiran dan emosi yang luas. Inilah

${ }^{44}$ Ahmad Fauzi, "Habitualisasi Nilai-Nilai Kepemimpinan Transformatif Perspektif Kiai Hasan Mutawakkil'Alallah, dalam Jurnal Manajemen Pendidikan Islam, Volume 3, Nomor 1, Mei 2018/1439, 2 pemimpin transformasional dimana perilaku tersebut diimplikasikan pada seluruh komponen organisasi pendidikan dengan cara inspirasional dan ide-ide atau gagasan yang tinggi sebagai motivasi yang ditanamkan pada seluruh santri. ${ }^{45}$

Untuk mencapai hal tersebut, santri lulusan dari pondok pesantren haruslah kuat dalam hal religi, dengan penerapan konsep agama bukan untuk dipelajari, namun diamalkan dalam keseharian di pondok pesantren, minimal tiga tahun dilakukan proses habitus, dan juga santri menguasai ilmu umum sesuai dengan kapasitas dan potensi yang dimiliki dan menjadi pilihannya. Hal ini senada dengan Yazid yang menyatakan bahwa proses transformasi nilai mengandung dimensi waktu dan perubahan sosial budaya masyarakat yang muncul melalui proses panjang dan selalu terkait dengan aktifitas-aktifitas yang terjadi pada saat itu. ${ }^{46}$

Keempat, dari santri tradisional menjadi santri milenial. Pandangan masyarakat yang selama ini masih menganggap santri 'kolot' sudah harus dihapuskan. Santri adalah sosok religious yang berwawasan global, berjiwa moderat, tidak gaptek terhadap perkembangan ilmu pengetahuan dan teknologi. Untuk menjawab itu semua tentunya pondok pesantren Amanatul Ummah tidak hanya diam namun menyiapkan para santrinya untuk terjun dalam kancah kompetisi lulusan santri. Dan faktanya hal itu bisa dicapai. Dalam perjalanan 5 tahun ke belakang, luusan santri pondok pesantren Amanatul Ummah diterima SPMB perguruan tinggi bonafit dan mengisi kuota terbanyak beasiswa se-Indonesia, yaitu 250 orang santri seperti: kedokteran (UIN, Unair, Unbraw, dan Unsud), selebihnya diterima di ITS, ITB, UGM, IPB, UIN Syahid, UIN Sunan Kalijaga, IAIN Semarang, dan lain-lain. Inilah kesuksesan

\footnotetext{
${ }^{45}$ Sri Rahmi, Kepemimpinan Transformasional dan Budaya Organisasi: Ilustrasi di Bidang Pendidikan, (Jakarta: Mitra Wacana Media, 2014), 155.

${ }^{46}$ Moh. Yazid, Transformasi Nilai, http://mohyazid168.blogspot.co.id/2016/02/transporma si- nilai-etika-dan-moral.html
} 
At-Turats

Jurnal Pemikiran Pendidikan Islam

journal homepage: http://jurnaliainpontianak.or.id/index.php/atturats

pengembangan lembaga pondok pesantren. Dengan capaian tersebut maka santri kolot terbantahkan dan berubah menjadi santri milenial.

Kelima, santri closed minded menjadi santri open minded. Mindset masyarakat tentanng santri adalah figure yang tertutup, hanya mengkaji agama dan mengkultuskan agama tersebut. Selama ini masyarakat memandnag bahwa santri hanya menguasai ilmu agama sehingga tidak membuka diri untuk hal-hal baru. Mindset ini yang dibongkar bahwa santri sekarang adalah santri yang open minded, selain menguasai ilmu agama juga menguasai ilmu umum. Nilai ini yang ditransformasikan kiai. Transformasi nilai yang digagas dan dibangun oleh kiai tersebut merupakan kekuatan dasar inovasi lembaga pendidikan yang diharapkan oleh masyarakat luas dan sebagai jawaban bagi orang tua untuk mensekolahkan anaknya di era modern yang ditandai dengan berkembangnya teknologi yang sangat canggih, namun nilai-nilai religious tetap ter-cover didalamnya. Hal ini selaras dengan konsep transformatif yang disampaikan oleh Kuntowijiyo, yaitu proses transformasi mengandung dimensi waktu dan perubahan sosial budaya masyarakat yang menempati yang muncul melalui proses yang panjang yang selalu terkait dengan aktifitas-aktifitas yang terjadi pada saat itu. Islam memiliki dinamika dalam transformasi sosial secara terus menerus yakni menegakkan amar ma'ruf dan nahi munkar dalam kerangka keimanan kepada Tuhan yang tak dapat dipisahkan dari transendensi. ${ }^{47}$

Berdasar paparan tersebut tergambar bahwa nilai yang diterapkan di pondok pesantren yaitu integrasi ilmu agama dan ilmu umum. Dimana internalisasinya membutuhkan kekuatasan dasar tersendiri, karena hal tersebut merupakan suatu power, yang ujung-ujungnya mampu menjadikan stimuli bagi santri itu sendiri. Dan hal inilah yang diharapkan dan ditunggu oleh para wali santri, dimana ada lembaga pendidikan

\footnotetext{
${ }^{47}$ Kuntowijoyo, Demokrasi dan Budaya Birokrasi, (Yogyakarta: Bentang, 1994), 338
}

mampu menggodog para santrinya menjadi pribadi yang religius, berkarakter, dan profesional dibidangnya. Bukti bahwa masyarakat mendambakan lembaga Amanatul Ummah adalah mereka menaruh harapan besar anaknya bisa studi lanjut ke jenjang perguruan tinggi bonafit, namun sudah memilliki dasar agama yang kuat.

Internasasi nilai-nilai intangible tersebut diwarnai dengan semangat untuk selalu menanamkan nilai-nilai Islami kepada santri. Nilai-nilai Islami selalu ditanamkan kepada santri supaya santri mempunyai bekal untuk menempuh kehidupan yang akan datang. Berpijak dari keterangan di atas, dapat dikemukakan bahwa MBI Amanatul Ummah menanamkan nilai-nilai Islam kepada santri melalui habitus, supaya santri mampu menghayati kehidupan dan sebagai bekal masa depan santri. Dalam habitus tersebut menunjukkan bahwa agama bukan untuk diajarkan melainkan untuk diterapkan.

\section{Proses transformasi nilai dalam inovasi kelembagaan Pondok Pesantren Amanatul Ummah}

Proses tranformasi nilai dalam inovasi kelembagaan dilakukan melalui beberapa hal yang terangkum sebagai berikut:
a. Al-jiddu wa al muwadlabah, yaitu berkesungguhan dan keajegan
b. Mudaawamatul wudlu', yaitu selalu menjaga diri dengan wudlu.
c. Taqliilul ghida', yaitu menyedikitkan makan. Artinya santri tidak akan makan sampai kekenyangan.
d. Qira'ah al-Qurani bi al-nadzar, yaitu membaca Al-Qur'an dengan melihat mushafnya langsung.
e. Tarkul ma'aashi, tidak boleh bermaksiat.
f. Melaksanakan shalat malam.
g. Tidak boleh jajan di luar dan ditempat-tempat terbuka.
h. Proses penanaman nilai dilakukan by modelling atau pelakonan.
i. Nilai agama bukan untuk dikaji melainkan untuk diamalkan dalam kehidupan sehari-hari, sebaliknya 
At-Turats

Jurnal Pemikiran Pendidikan Islam

journal homepage: http://jurnaliainpontianak.or.id/index.php/atturats

nilai-nilai umum itu untuk dipelajari dan dikaji.

Penanaman nilai ditanamkan langsung oleh kiai dalam kurun waktu terus menerus. Artinya bersifat kontinyu, mulai dari awal pendirian pondok pesantren di Surabaya hingga di Pacet Mojokerto. Penanaman nilai tersebut tidak sekadar ditanamkan begitu saja dan setelah itu finish, namun kesemuanya itu membutuhkan suatu proses. Proses tersebut tidak ditempuh dalam waktu instan, namun bersifat kontinyu dalam tenggang waktu yang tidak sedikit. Inilah proses inovasi yang dilakukan secara bertahap dan terusmenerus sehingga sampai pada tahap ultimate. Setiap santri minimal menempuh itu selama kurum waktu tiga tahun. Selain itu, hal yang perlu digaris bawahi adalah peran kiai yang terjun langsung sebagai pelaku atau pelakon dalam penanaman nilai-nilai tersebut tanpa diwakilkan. Hal ini belum dilakukan di lembaga pendidikan formal umum. Maka tidak heran kalau kata-kata "ngalap berkah" itu munculnya hanya di pesantren saja.

Proses internalisasi tranformasi nilai dalam inovasi kelembagaan yang dilakukan oleh pondok tersebut sebenarnya mengarah pada pembaharuan. Kegiatan pembaharuan misalnya, senantiasa berupaya untuk melakukan pembenahan-pembenahan pendidikan guna mencapai hasil yang lebih baik daripada hasil-hasil sebelumnya sehingga parameter yang digunakan adalah efektivitas dan efisiensi. Bagaimana mengefektifkan dan mengefisiensikan pelaksanaan pendidikan?, sehingga istilah perubahan mestinya bisa diganti dengan istilah inovasi. Price mencoba membedakan " Innovation is a less general term than social change, that is, any modification of the social structure and / or culture of a social system. All innovation is social change, but not all social change is innovation. ${ }^{48}$ (Pembaruan adalah istilah yang kurang umum dibanding perubahan sosial, yakni suatu modifikasi dari sebuah struktur sosial dan atau budaya dari sistem sosial. Seluruh pembaruan adalah perubahan social, tetapi tidak seluruh perubahan sosial merupakan pembaharuan.)

Sedangkan menurut Nursyam, karena ada beberapa hal, yaitu adanya inovasi yang datang dari dalam maupun dari luar, adanya motivasi kuat untuk berubah, dan ada skenario perubahan (perubahan akseleratif). ${ }^{49}$ Inovasi dari luar utamanya memberikan rangsangan untuk berubah, motivasi membangun kesadaran untuk berubah, sedangkan skenario mengadakan perubahan yang dikondisikan sesuai dengan program yang direncanakan. Dalam konteks kemasyarakatan, perubahan adalah hasil suatu masyarakat yang mencari cara memecahkan masalah yang diciptakan oleh perubahan dalam lingkungannya.

Dalam konteks lain, perubahan adalah pertumbuhan, perubahan adalah kesempatan, dan perubahan adalah peningkatan potensi. Dalam konteks ilmu social, perubahan merupakan hasil interaksi kepentingan yang secara ketat dikontrol, bahkan ditentukan oleh posisi sosial atau kondisi materiil elit yang terlibat. Perubahan dapat terjadi dalam bentuk perubahan yang direncanakan oleh para pimpinan baik karena faktor internal organisasi maupun akibat dorongan perkembangan lingkungan (planned changes). Pada pihak lain, ada perubahan yang terjadi tanpa perencanaan, atau mendadak karena

48 James L. Price, Handbook of Organizational Measurement, (London : DC. Health and Company, 1972), 118

49 Nursyam, "Indikator dan Pengukuran Pengembangan SDM di Pesantren", dalam A. Halim et. al., Manajemen Pesantren, (Yogyakarta : Pustaka Pesantren, 2005), 62 
At-Turats

Jurnal Pemikiran Pendidikan Islam

journal homepage: http://jurnaliainpontianak.or.id/index.php/atturats

ketidakpuasan dari para anggota organisasi terhadap situasi (unplaned changes $)^{50}$. Secara psikologis, perubahan yang pertama terjadi dalam suasana stabil sedang perubahan yang kedua terjadi karena konflik dan tidak jarang, selanjutnya mengakibatkan konflik yang berkepanjangan dalam organisasi.

Istilah perubahan mencakup perubahan ke arah negatif atau inefectif change dan juga partial change, namun kalau kata inovasi selalu mengarah kepada pembaharuan. ${ }^{51}$ Walaupun memang sebenarnya perubahan tersebut dimaksudkan untuk mengadakan pembaharuan untuk mempertahankan eksistensi lembaga, namun apabila tidak efektif maka tidak dinamakan pembaharuan atau inovasi. Maka lebih cocoknya dinamakan perubahan.

Sedangkan inovasi itu sendiri aka nada manakala ada proses transformasi nilai yang dilakukan dalam pembelajaran di pondok pesantren Amanatul Ummah yaitu melalui mata pelajaran, sebagai berikut: Setelah santri mengawali harinya dengan membaca al-Qur'an dengan membuka mushafnya langsung, santri sekolah madrasah diniyah, baru belajar formal. Dalam belajar formal, mata pelajaran yang disampaikan antara lain: Matematika, Fisika, Biologi Kimia, dan Bhs. Inggris, yang kesemuanya itu disampaikan/ diujikan dalam Bahasa Inggris. Sedang mata pelajaran agama dan bahasa Arab disampaikan/diujikan dalam Bahasa Arab. Setiap kelas rata-rata terdiri dari 25 siswa. Komunikasi

${ }^{50}$ Wahjosumidjo, Kepemimpinan Kepala Sekolah Tinjauan Teoritik dan Permasalahannya, (Jakarta: PT. Raja Grafindo Persada, 2002), 166

51 Inovasi mengacu kepada pembaharuan suatu produk, proses dan jasa baru. Lihat Lena Ellitan dan Lina Anatan, Manajemen Inovasi: Transformasi Menuju Organisasi Kelas Dunia, (Bandung: Alfabeta, 2009), 3. kesehariaanya menggunakan bahasa arab dan bahasa Inggris kecuali hari Ahad.

Adapun internalisasi nilai transformatif, pembelajaran umum dilakukan pasca pembelajaran agama. Pembelajaran umum meliputi: mata pelajaran Matematika, Fisika, Biologi Kimia, dan Bhs. Inggris yang kesemuanya itu disampaikan dengan menggnakan bahasa asing, Arab dan Inggris. Dan ujiannya dilaksanakan melalui dwi bahasa tersebut. Mengingat setiap kelas rata-rata terdiri dari 24 atau maksimal 25 siswa, maka pembelajaran bisa berjalan dengan lancar, artinya proses penanaman nilai juga bisa berjalan dengan baik.

Proses internalisasi nilai di pondok pesantren Amanatul terjadi selama 24 jam dalam pemantauan dan pengawasan para pengasuh dan ustadz/ah. Aktifitas belajar dan amalan religi yang dilakukan oleh para santri kadang membuat para sanatri lelah, namun karena sudah menjadi kebiasaan maka akan membentuk karakter pribadi santri yang tangguh. Ada waktu-waktu pembelajaran tertentu yang santri menjadi tidak fokus karena kelelahan, namun semua ilmu diawali dengan mengkaji agama dan membaca al-Qur'an, maka akan mendapat keberkahan. Internalisasi nilai ini artinya tidak bisa dilakukan secara instan, namun membutuhkan waktu dan dilaksanakan secara kontinyu.

Penanaman nilai di pondok pesantren Amanatul Ummah tidak hanya dalam hal itu, namun juga dalam pembiasaan gaya hidup dan berperilaku sederhana. Hal ini dapat dijelaskan sebagai berikut; Anakanak dalam seminggu tidak boleh pegang uang lebih dari 70 ribu, disinilah pembentukan karakter secara langsung diterapkan. Membawa HP tidak diperbolehkan. Kalau sampai ketahuan bawa HP maka aturannya HP harus 
At-Turats

Jurnal Pemikiran Pendidikan Islam

journal homepage: http://jurnaliainpontianak.or.id/index.php/atturats

dibanting, dan yang membanting adalah mereka sendiri. demikian juga lap top tidak diperbolehkan secara bebas, namun dalam situasi tertentu boleh, karena mereka ketika mengikuti lomba membutuhkan laptop untuk mencari informasi terkait dengan lomba tersebut. Jadi penggunaan laptop dibatasi dalam satu minggu ada beberapa hari yang boleh menggunakannya kecuali untuk kepentingan lomba.

Mengenai internalisasi nilai yang ditanamkan oleh kiai dalam menggembleng santri menjadi generasi yang tangguh dan religius adalah dengan selalu mengingatkan, memberi nasehat, sekaligus mencontohkan kepada para santri untuk selalu menjaga wudlu.

Dari uraian tersebut di atas, dapat dikatakan bahwa proses internalisasi nilai yang dilakukan oleh pondok pesantren, terintegrasi dalam kegiatan sehari-hari dan proses pembelajaran selama 24 jam. Semua proses internalisasi nilai tersebut dilaksanakan untuk pengembangan lembaga itu sendiri. Tanpa ada internalisasi nilai yang diterapkan, maka lembaga tidak akan bisa mengalami pengembangan, bahkan inovasi tidak akan tercapai.

Dari internalisasi nilai tersebut, menjadi kekuatan dasar inovasi kelembagaan. Beriring dengan perubahan mindset sebagai hasil dari transformasi nilai tersebut maka pondok pesantren juga mengalami perubahan, dari semula hanya pondok pesantren salafiyah menjadi ada madrasah unggulan, madrasah akselerasi, dan madrasah bertaraf Internasional. Hal ini disebabkan karena paradigma para santri maupun pengelola sudah beribah dalam menatap masa depan. Untuk mendukung inovasi kelembagaan tersebut, sarana prasana juga menjadi hal penting dalam inovasi kelembagaan. Dan pengembangan ini telah dilakukan oleh pondok pesantren Amanatul Ummah. Burhanuddin mengemukakan, sarana pendidikan adalah semua perangkat bahan, peralatan, dan perabot yang digunakan secara langsung dalam proses pendidikan di sekolah. Sedangkan prasarana pendidikan adalah semua perangkat kelengkapan dasar penunjang proses pendidikan yang digunakan secara tidak langsung, seperti lokasi atau tempat, bangunan sekolah, lapangan olahraga, ruang dan sebagainya. ${ }^{52}$ Sarana prasarana di pondok pesantren Amanatul Ummah telah lengkap bahkan melampaui dari hal tersebut, karena lingkungan alam sekitar pondok pesantren sangat mendukung sehingga bisa sekaligus sebagai laboratorium alam pun juga laboratorium ibadah. Di kedua laboratorium inilah proses penanaman nilai-nilai intangible dilaksanakan karena tempat ini merupakan tempat yang paling efektif mampu menyentuh kognitif, afektif maupun psikomotor santri, dengan pendekatan formal non-struktural dan budaya sekolah sebagaimana pendapat Muhaimin bahwa nilai bisa dibentuk melalui pendoktrinan nilai-nilai Islami yang dianut dan dipraktekkan dalam keseharian. $^{53}$ Ditambah lagi dalam pengembangan lembaganya, pondok pesantren Amanatul Ummah selalu dibarengi dengan kemampuan financial yang mendukung demi pengembangan lembaga. Dengan cara ini, maka inovasi bisa yang terlaksana. Tanpa adanya kemampuan financial yang mendukung, maka perubahan tidak akan mampu diwujudkan.

\footnotetext{
${ }^{52}$ Afid Burhanuddin, Manajemen Sarana Prasarana Pendidikan, diakses dari

https://afidburhanuddin.wordpress.com/.../manajemensarana-prasarana-pendidikan/, , pada tanggal 10-102018, jam 15.00

53 Muhaimin. Nuansa Baru Pendidikan Agama Islan, (Jakarta: Raja Grafindo Persada, 2006), 157-158
} 


\section{At-Turats}

Jurnal Pemikiran Pendidikan Islam

journal homepage: http://jurnaliainpontianak.or.id/index.php/atturats

Dari paparan tersebut di atas bisa diambil benang merah bahwa inovasi yang terjadi PP Amanatul Ummah melalui tahapan yaitu dari kondisi stagnan lalu ada proses penanaman nilai sebagai kekuatan dasar inovasi yang dipelopori oleh figure kiai yang bertindak sebagai visionary leadership, diintegrasikan dalam pembelajaran dan habitus santri, kajian menguatkan dengan pendapat Lewin, bahwa inovasi tidak akan dating begitu saja melainkan melalui tahapan yaitu kondisi unfreezing, cognitive restructuring (changing), dan refreezing. ${ }^{54}$ Penjelasan lebih lanjut sebagaimana dalam gambar berikut:

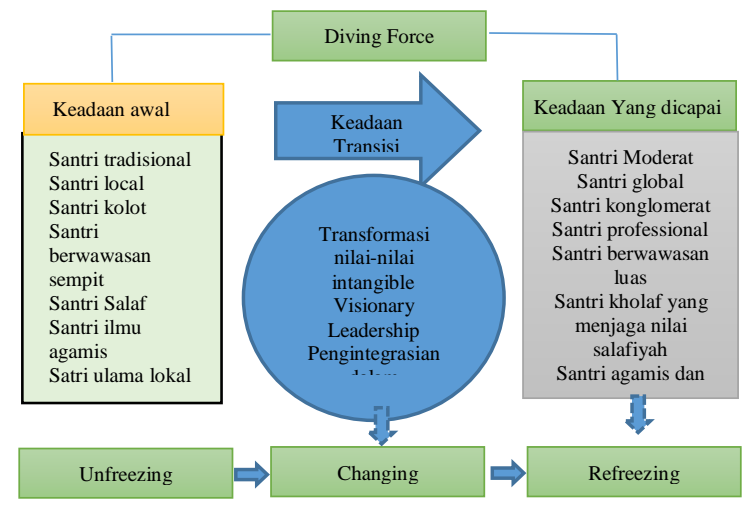

Inovasi kelembagaan yang dilakukan pondok pesantren Amanatul Ummah tersebut mendapat kepercayaan dari masyarakat secara penuh, terbukti dengan antusias dukungan baik material maupun non material, pun juga animo masyarakat sangat tinggi untuk menyekolahkan anaknya di pondok pesantren amanatul Ummah merupakan bukti nyata bahwa pondok pesantren ini telah melakukan inovasi dimulai dari transformasi nilai intangible sebagai kekuatan dasar

\footnotetext{
${ }^{54}$ Edgar H. Schein, Organizational Culture ..., 298
}

mencapai keadaan yang diinginkan. Model inovasi yang dilakukan tersebut senada dengan teori Lewin, namun ada hal yang berbeda yaitu pada proses changing, pondok pesantren mengkonstruk pandangan para santri dan pengelolanya dengan pendekatan integrated, yaitu dilakukan bersama-sama antara kiai, pengasuh, dan santri bersifat intangible, maksudnya nilai tersebut tidak kentara, tidak bisa diraba, namun ada dan terpatri pada diri santri dan semua pelaku yang ada di pondok pesantren selaras dengan visi misi yang diemban. Dan proses changing tersebut akan semakin kokoh manakala visionary leadership tangguh.

\section{PENUTUP}

Berdasar kajian tersebut di atas mengenai inovasi kelembagaan pondok pesantren melalui transformasi nilai bisa ditarik kesimpulan sebagai berikut: pertama, nilai-nilai yang dibangun sebagai dasar inovasi kelembagaan di Pondok Pesantren Amanatul Ummah adalah nilai intangible yang bersifat tidak kentara namun menjadi kekuatan dasar inovasi. Nilai-nilai yang ditransformasikan adalah perubahan mindset dari santri ulama lokal menuju santri ulama besar, dari santri agamis menjadi santri ilmuwan professional religius, dari santri pebisnis lokal menjadi santri konglomerat, dari santri tradisional menjadi santri milenial, dan dari satri closed minded menjadi santri open minded.

Kedua, proses inovasi dilakukan mulai dari transformasi mindset, self awareness, dan habitus. Dalam transformasi tersebut ada proses internalisasi nilai-nilai yang menjadi budaya organisasi pondok pesantren mulai dari kondisi unfreezing menuju changing dan dilanjutkan dengan refreezing dengan kiai yang memiliki visionary leadership sebagai 
penggeraknya. Inovasi kelembagaan tersebut tergambar dari kondisi pondok pesantren salafiyah menjadi berkembang dengan adanya Madrasah Tsanawiyah, Madrasah Aliyah, Madrasah Aliyah Unggulan, Madrasah Program Akselerasi, dan Madrasah Bertaraf Internasioanl (MBI).

\section{DAFTAR PUSTAKA}

Azra, Azyumardi, "Surau di Tengah Krisis: Pesantren dan Perspektif Masyarakat", dalam Rahardjo ed., Pergulatan Dunia Pesantren Membangun dari Bawah, Jakarta: LP3ES, 1985.

Bogdan, Robert C. dan Biklen Kopp Sari, Qualitative Research for Education: An Introduction to Theory and Methods. Allyn and Bacon, Inc.: Boston London, 1982.

Bridges, William, Managing Transitions: Making the Most of Change, Cambridge: Perseus Publishing Services, 2003.

Burhanuddin, Afid, Manajemen Sarana Prasarana Pendidikan, diakses dari https://afidburhanuddin.wordpress.com $/ \mathrm{m}$ anajemen-sarana-prasarana-pendidikan/

Ekosusilo, Madyo, Hasil Penelitian Kualitatif Sekolah Unggul Berbasis Nilai: Studi Multi Kasus di SMAN 1, SMA Regina Pacis, dan SMA al-Islam 01 Surakarta, Sukoharjo: UNIVET Bantara Press, 2003

Ellitan, Lena dan Lina Anatan, Manajemen Inovasi: Transformasi Menuju Organisasi Kelas Dunia, Bandung: Alfabeta, 2009.

Faisal, Sanapiah, Penelitian Kualitatif: Dasar-Dasar dan Aplikasi, Malang: YA3, 1990.

Fauzi, Ahmad, "Habitualisasi Nilai-Nilai Kepemimpinan Transformatif Perspektif Kiai Hasan Mutawakkil'Alallah, dalam Jurnal Manajemen Pendidikan Islam, Volume 3, Nomor 1, Mei 2018/1439.

Gie, The Liang, Pengantar Filsafat Ilmu, Yogyakarta: Liberty, 2010.

Hariadi, Farid Ma'ruf, "Arah Baru Pengelolaan Pondok Pesantren", dalam
Episteme Jurnal Pengembangan Ilmu Keislaman, vol. 3, Juni 2008.

James L. Price, Handbook of Organizational Measurement, London : DC. Health and Company, 1972, 118

Katsoff, Louis O., Elements of Philosophy, terj. Soejono Soemargono, Yogyakarta: Tiara Wacana, 1989

Koentjaraningrat, Kebudayaan, Mentalitas, dan Pembangunan. Jakarta: Gramedia, 1989

Komaruddin, Kamus Riset, Bandung: Angkasa, 1984

Kuntowijoyo, Demokrasi dan Budaya Birokrasi, Yogyakarta: Bentang, 1994

Langgulung, Hasan, Pendidikan Islam Menghadapi Abad ke-21, Jakarta: Pustaka Al- Husna, 1988.

Latif, Abdul, Pendidikan Berbasis Nilai Kemasyarakatan, Bandung: Refika Aditama, 2006.

Miles, B. Mathew dan Michael Huberman, Analisis Data Kualitatif Buku Sumber Tentang Metode-metode Baru, Jakarta: UIP, 1992.

Moleong, Lexy J, Metode Penelitian Kualitatif, Bandung: Remaja Rosda Karya, 1990

Muhaimin, Pengembangan Kurikulum Pendidikan Agama Islam di Sekolah, Madrasah dan Perguruan Tinggi, Jakarta: Raja Grafindo Persada, 2005

Muhaimin. Nuansa Baru Pendidikan Agama Islan, Jakarta: Raja Grafindo Persada, 2006

Mulyana, Rohmat, Mengartikulasikan Pendidikan Nilai, Bandung: Alfabeta, 2004

Nata, Abuddin, Sejarah Pertumbuhan dan Perkembangan Lembaga-Lembaga Pendidikan Islam di Indonesia, Jakarta: Grasindo, 2001

Nursyam, "Indikator dan Pengukuran Pengembangan SDM di Pesantren", dalam A. Halim et. al., Manajemen Pesantren, Yogyakarta : Pustaka Pesantren, 2005.

Patoni, Achmad, Peran Kiai Pesantren Dalam Partai Politik, Yogyakarta : Pustaka Pelajar, 2007. 


\section{At-Turats}

Jurnal Pemikiran Pendidikan Islam

journal homepage: http://jurnaliainpontianak.or.id/index.php/atturats

Rahardhjo, Dawam, Pesantren dan Pembaharuan, ttp: LkiS, 1995.

Rosyadi, Khoiron, Pendidikan Profetik, Cet.1 Yogyakarta: Pustaka Pelajar, 2004

S. Wojowasito, Tito Wasito W, Kamus Lengkap Inggris-Indonesia, IndonesiaInggris, Bandung: Penerbit Hasta, 1982.

S.P. Robbins, Organizational Behaviour, New Jersey: Prentice Hall, Inc, 1991.

Schein, Edgar H., Organizational Culture and Leadership, San Fransisco: JosseyBass, 1997.

Sofia, Aya, et.al., Pedoman Penyelenggaraan Pusat Informasi Pesantren, Jakarta: Proyek Pembinaan dan Bantuan Kepada Pondok Pesantren di Jakarta 1985/1986.

Sri Rahmi, Kepemimpinan Transformasional dan Budaya Organisasi: Ilustrasi di Bidang Pendidikan, Jakarta: Mitra Wacana Media, 2014.

Tolkhah, Imam dan Barizi, Membuka Jendela Pendidikan-Mengurai Akar Tradisi, Jakarta: PT. Raja Grafindo Persada, 2004.

Wahjosumidjo, Kepemimpinan Kepala Sekolah Tinjauan Teoritik dan
Permasalahannya, Jakarta: PT. Raja Grafindo Persada, 2002.

Wibowo, Manajemen Perubahan, Jakarta: PT Raja Grafindo Persada, 2006.

Winardi, Manajemen Perubahan, Jakarta: Kencana, 2005.

Wiriaatmaja, Rochiati, Metode Penelitian Tindakan Kelas, Bandung: PT. Rosdakarya, 2007.

Yasmadi, Modernisasi Pesantren, Kritik Nurcholis Madjid terhadap pendidikan islam tradisional, Jakarta: Quantim Teaching, 2005.

Yazid, Moh., Transformasi Nilai, http://mohyazid168.blogspot.co.id/2016/0 2/transpormasi- nilai-etika-danmoral.html

Dapat kita dideskripsikan bahwa sarana dan prasarana merupakan unsur penunjang dalam pelaksanaan 